\title{
Old Scandinavian and Christian Eschatology
}

\author{
BY ANDERS HULTGÅRD
}

The eschatological beliefs current in Scandinavia during the Viking and early Medieval periods can be grouped into two main traditions, denoted by the concepts of Ragnargk and Doomsday. The former has its roots in the pre-Christian religion of Scandinavia, the latter was brought to the north in the process of christianization. Although different in origin the two traditions did not, in the age with which we are concerned, necessarily reflect a strict division between adherents of the old faith and Christians. Syncretic versions of the Ragnarok concept were in circulation, one of which was presented by Snorri in his Edda (Snorri 1968, $51 \mathrm{ff}$.). The common people, although officially christianized, apparently continued to transmit beliefs connected with the Ragnargk tradition.

Scholarly research has tended to treat the two traditions separately. In fact they coexisted for centuries, leaving room for confrontation and mutual influences. The purpose of the present paper is to elucidate certain presuppositions and to examine aspects of that encounter. A full treatment of Old Scandinavian eschatology will be reserved for a monograph in preparation. ${ }^{1}$

As indicated by the key words Ragnarogk and Doomsday, this study deals primarily with what is referred to by comparative religion as general or universal eschatology (cf. Widengren 1969, 440): that is to say, ideas and myths describing great and decisive events in the future which concern the world and mankind as a whole, a nation or group of people. By contrast, individual eschatology is concerned with the destiny of the single person in and after death. Individual eschatology is part of the general eschatology in cases where the individual after death shares in the fate of mankind and the world. In Christianity, the soul of the individual awaits the general resurrection of the dead at the Day of Judgement. According to some Old Norse texts, the heroes who fall in combat are taken to Valhọll by Óðinn and his valkyriur as kinds of recruits for the final battle against the forces of Evil at the

1 Hultgård, A. Ragnargk and Valhgll - aspects of the world-view of the ancient Scandinavians. 
time of Ragnargk (Eiriksmál. SKJ 1908-15, 1, 174 f.; Snorri 1968, $106 \mathrm{f}$.).

Historians of religions who intend to describe the development and encounter of the Ragnarok and Doomsday traditions are hardly to be envied. They are far from the ideal situation in having two distinct groups of sources to start with, one representing the pre-Christian Scandinavian religion, the other medieval Christianity, and then to follow up with a third group of sources in which the confrontation of the two traditions could be recorded. Instead, the scholar has to work with a rather scanty source material which is one-sided in more than one way. The literary texts that have been preserved originate almost exclusively from Iceland and Norway whereas for Denmark and Sweden the evidence is roughly limited to runic inscriptions, which are short and convey a stereotyped content. The bias is less striking with the iconographic material, but even here the pictures on rune stones and the limited number of early church paintings in Denmark and Sweden (eleventh and twelfth centuries) cannot compete with the uniqueness of the material presented by the Norwegian stave churches. Moreover, the sources preserved derive almost entirely from the winning side, the Christian church and its ally, the central power embodied in the newly emerged national kingdoms of Scandinavia. What has been left of the pre-Christian tradition is to a large extent already marked by the encounter with the penetrating European-Christian civilization.

\section{Christian eschatology in Scandinavia}

Christian doctrines were chiefly propagated from holy books and other religious writings. The eschatological teachings brought to Scandinavia were found in a diversity of documents such as copies of the Bible, liturgical books, collections of edifying texts, learned works by theologians. For the spread of eschatological ideas the main question is, however, to assess the range of the various documents, their capacity of influencing the great majority of the Scandinavian people.

With the Bible, represented by the Latin Vulgate, we are at the centre of institutionalized Christianity. As official canon of the RomanCatholic church it is the basis of teaching and tradition. The most important eschatological and apocalyptic texts are found in the section of the gospels of Matthew, Mark and Luke known as "the synoptic apocalypse" ${ }^{2}$, the judgement teaching in Matthew 25, the Book

2 Matthew 24, 3-44; Mark 13, 5-37; Luke 21, 8-36. 
of Daniel chapters 7-12, and the Revelation of John. In the Latin Vulgate there is another important apocalypse named, IV Esdras ${ }^{3}$, with extensive eschatological passages. Through the books used in the service much of the biblical eschatology acquired a firm cultic setting. Besides the biblical canon, its paraphrases and the liturgical books, large parts of the ecclesiastical literature in Latin found their way to $S$ candinavia. These texts did not have the same dogmatic and ritual significance but they often served the purpose of transmitting and interpreting the contents of the canon and the meaning of the liturgy.

Knowledge of the eschatology in the Latin texts mentioned was certainly restricted to a small number of people related to the episcopal sees and the monasteries. Only a few copies of the whole Vulgate would have been in circulation within the Scandinavian area and other Christian books in Latin were available chiefly at the monastic and cathedral schools. Bishops, literate monks and clerics, and also some lay members of prominent families were those who had access to the Christian Latin eschatology. The majority of the priests, those who served among the common people, certainly did not know more Latin than was required to read the mass properly.

When there was need for it, the eschatological teachings hidden in the Latin Vulgate could be activated and assume new functions. A good example of this is the donation letter of King Knut to the cathedral of Lund in 1085. The document ${ }^{4}$ which is in Latin contains towards the end the following words:

If anyone in his haughtiness, be he of noble or low rank, born or unborn, inflated with arrogant audacity against the statutes of the holy religion attempts to violate what has been decreed in this treaty, he shall be cursed at the coming of the Lord (sit anathema maranatha). He shall be determined to eternal punishment where the worm shall not die and the fire shall not be quenched. May his table before him be made a snare, a retribution and a stumbling-block together with those who said to the Lord God: go away from us, we do not want to know your ways.

Using various biblical passages a literate cleric in the episcopal chancellery has composed an imprecatory formula, the effect of which is greatly enhanced by the reference to the last judgement. Such curse

3 This text which belongs to the so called deutero-canonical books of the RomanCatholic church, also has the title in some editions of The Second Book of Esdras.

4 The text is preserved in a twelfth century ms. called Necrologium Lundense. 
formulas have roots far back into the antiquity of the Mediterranean world but here they seem to continue native genres from the Viking period. Some runic stones in southern Scandinavia ${ }^{5}$ present us with similar curse formulas which may contain eschatological hints ${ }^{6}$.

The most important way, however, by which Christian eschatological ideas were propagated was through translations and adaptations of ecclesiastical literature into the vernacular language. These works had a far greater social range of influence since they were used in the education of the many parish priests who spread much of the contents to the broad mass of the people through preaching and recitation, particularly at the sunday services and on feast-days. In addition, part of the education received by members of chieftain- and prominent landowning families no doubt included some knowledge of this translation literature.

The earliest texts to be written in Old Norse consisted of religious literature brought to Scandinavia with christianization. This literature was translated mainly during the twelfth century. Important texts of this kind were the Dialogues and Homilies of Gregory the Great, the summa of Christian theology entitled Elucidarius, saints lives, Niðrstigningarsaga and the parenetic and didactic texts collected in the Old Norwegian and the Old Icelandic Homily-Books. These collections include several pieces which, in their Old Norse version, most probably go back to the end of the eleventh cent ury. A particular genre is the vision literature which is also represented in some of the texts just mentioned. As independent works in prose or poetry, however, they flourish chiefly in the thirteenth and fourteenth centuries ${ }^{7}$. The vision literature is centered around the destiny of the individual after death and contains little universal eschatology.

The homilies as we have them are not literal reproductions of the early missionary preaching, but they constitute nonetheless, I believe, true reflections of the religious ideas and ethical teachings with which the Scandinavians were confronted during the Viking period. The

${ }^{5}$ The inscriptions are: the Glavendrup and Tryggevælde stones (Fyn and Sjælland respectively) from the early tenth century and the Sønder Vinge stone 2, the Skern stone 2 (both from North Jutland), the Glemminge stone (Skåne) from c. 1000.

- I venture the suggestion that the threat to become a rete (the word is unexplained) on most of these stones might have something to do with man's conditions after death.

7 Among the more important Old Norse visionary texts from that period we find the poems Sólarlió and Draumkvaedet, besides Dougal's Vision and Rannveigar leizla. 
Homily-Books refer repeatedly to the Last Judgement and its consequences for the world and for mankind. The bliss of heaven given to the righteous and the eternal punishment in hell allotted to the impious are intensely depicted. This eschatological message seems to have been one of the most prominent features in the preaching of the missionaries. In the introduction to the 'Life of St. Olaf' as recorded in the Old Norwegian Book of Homilies (GNH 1931, 108, 26-29) it is said that the Lord sent men with a firm faith to Norway in order to convert the inhabitants from their idolatry (frá heidnum blótum) by promising eternal life and happiness for those who believed in God and threatening the evil ones (read: those wo did not convert) with doomsday and the tortures of hell. These early missionary sermons, presumably delivered orally with or without the help of interpreters ${ }^{8}$, have been lost but their impact can be deduced from other sources.

Christian skaldic verse sometimes refers to eschatological matters. For example, in a stanza attributed to Hallfreðr Óttarsson Vandræðaskald (c. 1000) the poet seeing death draw near confesses that he fears nothing except hell (lv. 28; SKJ 1908-15, 1, 173.). Arnórr Jarlaskald alludes in a stanza to the role of the angel Michael at the last judgement (SKJ 1908-15, 1, 353.). The numerous rune-stones in Sweden from the eleventh century often contain inscriptions which end with a Christian invocation: "God (or Christ) help his soul" " This formula must be understood against the preponderance of eschatological themes in the first missionary preaching as it is reflected in the oldest Homily-Books. The runic invocations express the hope that the person commemorated might be saved from the torments of hell and come to the joy of heaven. On some stones the little word "well" is added to the inscription as for instance on a stone from Levene church in Västergötland (Vg 117) where we read: "God help their souls well". This may be compared with similar expressions found in the early homilies e.g. GNH 1931, 32, 18-19. Having described the bliss of heaven, the author exclaims: "well is it for their soul who can attain that kingdom and the glory which is there, although they were born in the world" (val er peirra sálu at peir i vergldu bornir váru er pat riki megu fá ok bá dýrd er par er).

Literacy and preaching were not the only ways by which the Christian eschatology spread throughout Scandinavia. Of equal importance

8 For a discussion of missionary methods see Sawyer \& Sawyer \& Wood 1987, 8 f., $24 \mathrm{ff}$.).

9 Several variants of this basic formula occur. 
was the pictorial art found in the churches and on independent monuments. Wall paintings, decorated portals, pictures on baptismal fonts conveyed the message of doomsday and the last times to the common people who gathered at the sacred places of the new religion. Memorial stones and funeral monuments could also transmit eschatological teachings in pictures.

\section{The Ragnarok-tradition}

The origin and transmission of the Old Norse ideas of Ragnargk are far more complicated than those of their Christian counterparts. The main problem may somewhat drastically be put in the following terms: did the pre-Christian Scandinavians possess an eschatological tradition of similar extent and coherence as that presented by Snorri in his Edda? Different answers have been given to that question and I shall not repeat them here. However, to set the religio-historical problem in the right perspective, an attempt must be made to elucidate the transmission history of the Ragnarok-tradition and evaluate the various forms in which it has come down to us.

In the first place we have allusions in skaldic poetry which are generally held to refer to events in the Ragnargk drama. The genre in which these references are embodied ranks high regarding reliability of transmission. Date and authorship of skaldic stanzas can usally be established with confidence. Some Ragnargk motifs such as the impending assault of the Fenrir-wolf, the battle between Óðinn and the wolf, the return of Baldr after the end of the present world, can thus be placed in the milieu surrounding West Norse warlords and chieftains of the late tenth century. The problem with these brief skaldic allusions is that we ignore their larger mythical context and have to rely on Veluspá and Snorri for a reconstruction.

Similarly, eddic poems such as Vafprúdnismál and Lokasenna, record in an allusive way eschatological events which reappear as elements of a coherent Ragnargk myth in Vgluspá and Snorri. The poems are not dateable in the same manner as skaldic verse nor are their original setting known. All that can be said is that they have been transmitted orally on Iceland in Christian time - for how long is a matter of conjecture - before they were written down on parchment in the course of the thirteenth century.

It is only in the poetic compilation of mythic material known as Voluspá that we find a kind of coherent eschatological doctrine. The 
date and the original wording of Vgluspá cannot be ascertained with any precision. The poem has come down to us in three different versions $\mathrm{s}^{10}$ committed to writing independently and based on oral tradition, as pointed out by Jón Helgason (Vgluspá 1971, V-IX). Two of these versions, the Codex Regius and the 'Vorlage' of Snorri were written down in the thirteenth century and the one in Hauksbók presumably in the middle of the fourteenth century. Assuming that Voluspá took shape as a distinctive piece of oral tradition around 1000, which is the usual date put forward, we must account for a transmission period of at least two centuries after the official acceptance of Christianity on Iceland. The differences shown by the three versions make it clear that the oral tradition was subject to change and not always reliable in details.

A minor eschatological section is found in stanzas 42-44 of Hyndluliód presumably part of an independent poem called by Snorri "the short Voluspa" (Snorri 1968, 5). Hyndlulió is preserved in the Flateyarbók from the late fourteenth century but through the use made of it by Snorri the eschatological part can be traced back to the early thirteenth century.

The most complete description of Ragnargk and related eschatological events is found in the Edda of Snorri Sturlason, more precisely chapters 51-53 of Gylfaginning. The original text has been slightly altered as may be deduced from an analysis of the surviving manuscripts ${ }^{11}$, but structure and contents faithfully reproduce the author's intentions. We meet in Gylfaginning a learned mythographer with Christian education who systematizes and harmonizes his sources and who does not refrain from introducing here and there Christian ideas and terms in his presentation of Old Norse mythology. The material he has collected from native tradition remains, however, a prime source of knowledge for the study of the Ragnargk myth.

The survival of pre-Christian ideas of Ragnargk long after the official acceptance of Christianity, although not in unchanged form, and the early spread of Christian eschatological doctrine in Scandinavia indicate a period of two to three centuries during which an encounter between Christian and Old Norse eschatology could take place.

The documents and pictorial art through which Christian eschatology was propagated represent the official and normative religion. The

10 Two versions, those in Codex Regius and Hauksbók, are more or less complete and the third has been partly preserved by Snorri in his section on Ragnarok.

11 None of the manuscripts seems to represent the original version of Snorri's Edda.

Cf. Prologue 1982, 31. 
setting in life of most of the Christian texts and monuments can be determined with a high degree of certainty. As to the Ragnarok tradition, it is only the version given by Snorri in his Edda for which we are able to establish function and context accurately. Provided that the attribution of skaldic stanzas has been correctly preserved by Icelandic and Norwegian tradition, we can come close to an understanding of their original setting. However, the few eschatological allusions in preChristian skaldic verse are deprived of their original mythical context. The extent and ritual background of this religious tradition remain unknown to us. When we come to Vgluspá and other eddic poems, there is next to nothing on which to base our judgement of date and original setting.

In order to evaluate the pre-Christian charachter of the Ragnargk ideas one must nevertheless attempt to elucidate the question of which milieu and which literary forms kept these ideas alive. Thus, it is important to know whether a Ragnargk statement was being diffused as an easily altered piece of popular narrative lore or was firmly handed down in a ritual context by religious specialists. There may be other contexts as well. The antiquarian interest of the twelfth century writers in history and ancient lore might have given rise to learned constructs of eschatological statements. However, the context given by Snorri in Gylfaginning for some Ragnargk motifs makes them more reliable from the view-point of transmission. He tells us that during the cosmic upheavals before Ragnargk proper the ship Naglfar which is made from the nails of dead men comes loose, and he continues:

it is worth caution that if a man dies with uncut nails, he will supply much material to the ship Naglfar which gods and men wished had never been built (Snorri 1968, 69).

A little further on, Snorri describes how Viðarr takes revenge on Óðinn by putting his foot on the lower jaw of the wolf and with his hand on the upper jaw tearing asunder the mouth of the beast. Snorri also makes the following remark:

On this foot he wears that shoe for which material has been collected through all times, that is the (waste) scraps which men cut from their shoes at the toes or the heel. This is why the man concerned about coming to the aid of the esir, should throw those scraps away (Snorri 1968, 71).

These examples show that some Ragnargk motifs still circulated among common Icelanders in the early thirteenth century. The motifs were 
associated with particular situations and had in this way been closely bound up with the life and work of the people. Under such circumstances one may assume a longer period of unbroken transmission.

For the purposes of comparison with the Ragnargk tradition it is methodologically appropriate to use, in the first place, the eschatological texts, regarding which there is evidence that they reached Scandinavia with christianization and were spread here in the vernacular language. It will not be sufficient to refer to biblical parallels, for instance from the Revelation of John which often figures in the discussion of Christian influence on the Ragnargk myth, although its eschatological sections are rarely cited in Old Norse literature. One must also examine to what extent biblical texts, hidden in the Latin Vulgate, actually influenced the carriers of native traditions among the broad mass of the people. Here the parenetic-didactic texts in the vernacular constitute the primary material of reference, not only to evaluate the Christian influence exerted on the Ragnarok tradition but also to determine what might have been genuine pre-Christian beliefs about the end of the world.

\section{Christian and Old Scandinavian eschatology}

The Christian eschatology as found in the vernacular sources presents a varied character. There is, however, agreement on those points which are firmly grounded in the doctrine of the Christian church: the coming of Christ in the last days, the ressurrection of the dead, the final judgement, the separation of righteous men and sinners, the end of the present world, the bliss of paradise and the torments of hell. These motifs appear from a temporal viewpoint as succeeding events of a great eschatological process.

Around this main complex of events a number of additional motifs and happenings are often grouped, such as Antichrist, his rise and fall, the signs of the end and the cosmic upheavals.

In the oldest parenetic and didactic texts interest in the last judgement and its consequences for man is prominent. Most sermons contain one or more passages on doomsday describing or alluding to the happiness of paradise and the torments of hell. The descriptions of heaven and hell are often formalized, presenting opposing 'lists' of qualities. As an example, we may take the Sermo necessaria of GNH $1931,87,12-89,12$ where the single groups of elements are introduced by an emphatic par "there": 
The kingdom of heaven is so good that no man can imagine it or tell it to anybody else.

There, everlasting life and eternal light are found,

there, delight and joy and all sorts of beauty exist, glory and happiness

without end.

There, a man will not fall ill nor will he be over-aged.

There, no hunger and thirst are found, no anxiety and sorrow.

There, every man always loves his fellow man as himself.

There, all good men shall see God for ever and ever and live with him and his angels in eternity.

Happy are those men who will experience such things.

But they are unhappy who will fall down to hell.

There they shall be with the devils.

There eternal darkness, disease, anxiety and sorrow are found, hunger and thirst, terrible cold and strong heat,

the greatest torments, and all without end.

All those men who come to that evil place, they shall never have hope for mercy afterwards.

This recurrent eschatological preaching has certainly prompted Snorri to include in Gylfaginning a passage on heaven and hell after the passing of the gods and the destruction of the world by fire (Snorri $1968,74)$ This passage reveals both in terminology and subject matter a Christian inspiration. Snorri draws partly on Voluspá and places its description of the punishments on the shore of corpses (Nástrond) in the future in accordance with the doomsday tradition. Voluspá may in turn depend on Christian visionary literature for certain motifs found in stanzas 36-39 (cf. Strömbäck 1980-82).

Coherent accounts of the universal eschatological process are comparatively few in early Old Norse literature. The sermon Admonitio valde necessaria in GNH 1931, 101, 15-102, 11 describes briefly the main events which will occur in the last days. After stating that the soul of man is immortal the author explains the meaning of doomsday and continues:

Then our lord Jesus Christ shall come out from heaven to hear our answers and recompense us for that which we have done, thought and spoken in this world. At the day of judgement every man who is misled (of-villtr) and does not make atonement for his sins and evil deeds, will receive a heavy and bad reward. No man has been born who would be so wise or so well-learned that he would be able to tell the kind of portents which will appear in the world just before the day when our lord comes forth from heaven to the great assembly. There all mankind shall come to meet him. Then the whole 


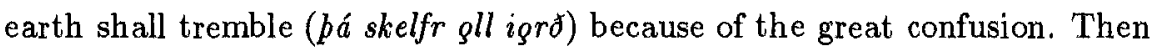
the burning fire shall flow forth from heaven and out of that fire the wide world shall burn. Hills and stones will then run as hot wax and seething lead. Through that fire all people shall pass to that judgement with which our lord shall recompense each one for the good and evil that every man has performed here (GNH 1931, 101, 26-102, 4).

The cataclysms of the last day are also mentioned in 47, 16-18:

The stars will fall from the sky and the powers of the heavens will be shaken before the appearance of the lord when he comes to judge all men.

The first part is taken from Matthew 24, 29 but quotations from eschatological passages in the Bible are in general rare in Old Norse literature as may be evidenced from a study of Kirby 1975. The only passage which has left a clear mark is the parable of the last judgement in Matthew 25, 31-46.

In this context mention should be made of a runic inscription from Södermanland in Sweden (Sö 154: the Skarpåker-stone) which alludes to cosmic upheavals. Whether one reads with von Friesen 1933, $158 \mathrm{ff}$. and Jansson 1963, 142 iard skal rifna ok upphiminn or with Kabell 1961, $53 \mathrm{ff}$. igrd skal rifna ok svá himinn, the eleventh century stone with its Christian iconography conveys a written message of the last day which is unique for the East Scandinavian area.

The eschatological teachings embodied in the Old Norse literature of the twelfth century are of fundamental importance for evaluating the influence exerted on the forms that the Ragnarok tradition took during the twelfth and thirteenth centuries. Vocabulary and themes in the eschatological section of Gylfaginning, for example, seem in some places to have undergone a clear Christian influence. The occurrence of the term vistir to denote the mansions of Gimlé recall the use of the same word for the heavenly dwelling-places in the Homily-Books (e.g. GNH 1931, 101, 12; HB 43, 18) Snorri's description of the cosmic cataclysms is another example. The phrases stigrnurnar hverfa af himninum (cf. also Voluspá 1971, 57) and svá skelfr iørð gll ok biørg at... suggest an adaptation to Christian eschatological diction.

Certain themes in the Ragnarok tradition most probably also originate from Christian doctrine (cf. above and the discussion in Olrik $1922,125-132$ ) or have been given their prominent place through the encounter with Christian ideas (cf. Schier 1981, 417 ff.)

The problem of foreign influence on the Ragnarok tradition appears rather complicated. In the first place, we have to consider the medieval Christian eschatology, secondly the possible penetration 
of Near Eastern ideas into pre-historic Scandinavia and third, the survival in the north of ancient Indo-European elements. In addition, Christianity in the Middle Ages continued a Jewish-Christian tradition which in its eschatological teaching had been clearly influenced by Iranian ideas. The Admonitio valde necessaria cited above displays a striking similarity with the Old Iranian concept of the eschatological fire which burns the world and melts the metal in hills and mountains. All men must then pass through the fire streams to be judged (see in particular Bundahišn 1908, 226 f.; Zand-Akasih 1956, 34, 18 f.). This ressemblance can best be explained by the circumstance that the medieval homily preserves an eschatological theme taken over from Iran at an earlier stage by Jewish-Christian tradition. The Christian visionary literature of the early Middle Ages shows more examples of such borrowings which ultimately stem from the Iranian eschatology e.g. the bridge over which men have to pass in order to arrive in paradise (cf. Strömbäck 1980-82). The Iranian idea of the eschatological fire and men's passing through it has been adduced as a parallel to Voluspá 39: sá hón par vaða punga strauma... with the explanation that Vgluspá here draws on a common Indo-European heritage (Ström $\AA .1967,190$ ff.). The theme, although originally Iranian, may as well have reached the author of Voluspá through the intermediary of Christian eschatological legend.

The study of the early Christian literature in the vernacular enables us not only to assess its impact upon native Scandinavian beliefs and ideas, but also to see more distinctly the genuine pre-Christian elements of the Ragnargk tradition. For example, the idea of the world's renewal with its emphasis on nature which is attested both in Vafbrúdnismál and V̧luspá seems to have no equivalent in the Christian eschatology as it is found in Old Norse religious texts. One may point to Revelation $21: 1$ where the visionary sees a new heaven and a new earth according to the divine promise in Isaiah $65: 17$. This short statement which is not further elaborated in the biblical passages mentioned has left practically no traces in Old Norse literature ${ }^{12}$ and cannot be the source of the cosnic restoration described in some eddic poems and in Snorri's Edda.

The main religio-historical question of whether the pre-Christian Scandinavians possessed a coherent eschatological tradition is difficult to answer solely by referring to medieval Christian doctrine. Descrip-

12 Isaiah $65: 17$ is quoted once in the preserved Old Norse literature. Elucidarius 71, cf. Kirby 1975, 105. 
tions of the whole eschatological process are less prominent in the vernacular religious texts than might be expected with regard to the assumption of a Christian impetus behind the growth of a coherent Ragnarok tradition. On the other hand comparative data from Iranian and Indian religions suggest the existence of an eschatological tradition also among the ancient Germanic peoples, which has been lost but is echoed in the early medieval Ragnarok tradition.

The penetration of the Christian eschatology in the north led to the assimilation of some motifs and details into the Ragnargk tradition which produced syncretic versions. There is very little in the Old Norse literature of the twelfth century to prove the opposite tendency. It seems to me quite natural that, once established, the Christian church with its self-confidence and contempt for 'paganism' had no real interest in adapting its preaching to pre-Christian beliefs. The occasional use of single mythological terms like Miðgarðs ormr for Satan-Leviathan in some early translations of Latin texts such as the Nidrstigningar saga is but the exception that proves the rule.

The period for an encounter which would have given rise to adapted forms of Christian eschatological thought in Scandinavia is the tenth and eleventh centuries but for such syncretism we have to rely almost exclusively on iconographical evidence.

\section{Bibliography}

Bundahišn. 1908. The Bundahishn, Being a facsimile of TD Manuscript No. 2. Ed. by T. D. Anklesaria. Bombay.

Friesen, O. v. 1933. Runorna. Nordisk Kultur 6. Oslo.

GNH Gammal Norsk Homiliebok, Cod. AM. 619 4. 1931. [Ed. by] G. Indrebø. Oslo.

HB Homiliu-Bók. 1872. [Ed, by] Th. Wisén. Lund.

Jansson, S. B. F. 1963. Runinskrifter i Sverige. Uppsala.

Kabell, A. 1961. A pokalypsen i Skarpåker. Arkiv för nordisk filologi 76. Lund. Kirby, I. 1975. Biblical quotation in Old Icelandic-Norwegian religious literature 1 . Reykjavik.

Nidrstigningarsaga. 1985. [Ed. by] O. E. Haugen. Bergen.

Olrik, A. 1922. Ragnarök - Die Sagen vom Weltuntergang. Berlin und Leipzig.

Prologue and Gylfaginning. 1982. Edda Snorri Sturluson. Ed. by A. Faulkes. Oxford.

Sawyer, B. \& Sawyer, P. \& Wood, I. 1987. The Christianization of Scandinavia. Alingsås. 
Schier, K. 1981. Zur Mythologie der Snorra Edda: Einige Quellenprobleme. Speculum norroenum. Ed. by U. Dronke et al. Odense.

SKJ Den norsk-islandske Skjaldedigtning A (diplomatic text). 1-2. 1908-15. [Ed. by] F. Jonsson. København.

Snorri Sturluson. 1968, Edda. Gylfaginning og prosafortellingene av Skáldskaparmál. [Ed. by] A. Holtsmark \& J. Helgason. (Nordisk filologi. A. Texter 1.) København.

Ström, A. V. 1967. Indogermanisches in der Völuspá. Numen 14. Leiden.

Strömbäck, D. 1980-82. Visionsdiktning. Kulturhistorisk leksikon for nordisk middelalder 22. [København.]

Widengren, G. 1969. Religionsphänomenologie. Berlin.

Voluspá, Hávámál. 1971. Eddadigte 1. [Ed. by] J. Helgason. Oslo.

Zand-Akasih. 1956. Iranian or Greater Bundahišn. Translit. and transl. by B. T. Anklesaria. Bombay. 